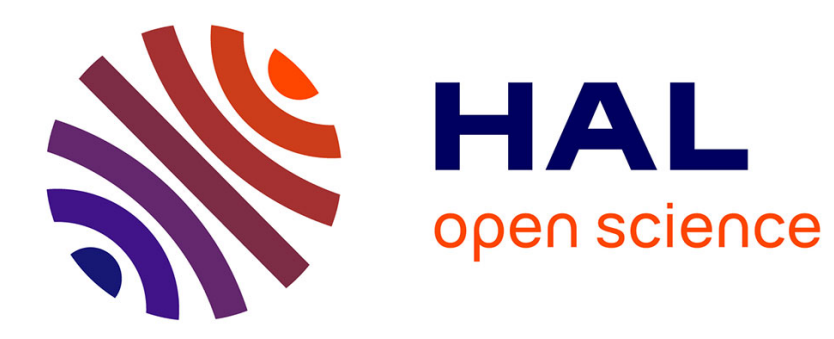

\title{
on the powers and limits of literature
}

Alain Ricard

\section{To cite this version:}

Alain Ricard. on the powers and limits of literature. Chabal, Engel, de Haan. african alternatives, brill, pp.21 -35, 2007, Africa Europe Group for Interdisciplinary Studies. halshs-00320565

\section{HAL Id: halshs-00320565 https://shs.hal.science/halshs-00320565}

Submitted on 11 Sep 2008

HAL is a multi-disciplinary open access archive for the deposit and dissemination of scientific research documents, whether they are published or not. The documents may come from teaching and research institutions in France or abroad, or from public or private research centers.
L'archive ouverte pluridisciplinaire HAL, est destinée au dépôt et à la diffusion de documents scientifiques de niveau recherche, publiés ou non, émanant des établissements d'enseignement et de recherche français ou étrangers, des laboratoires publics ou privés. 


\section{ON THE POWERS AND LIMITS OF LITERATURE}

\section{Alain Ricard}

In a recent special issue of Research in African Literatures (Fall 2006), Karin Barber and Graham Furniss call for renewed attention to African literature in indigenous languages. They notice that 'postcolonial literary theory has tended to overemphasize writing in English as the site of the postcolonial imaginary' (2006: 4). We could replace English by French and share the diagnosis! One of the effects of this overemphasis has been 'a focus on the relation of postcolonial literature to the metropolitan centre and on the identity of the nation state.' It is time to read differently and to read different texts.

This is the kind of alternative approach on which we want to focus: writing in African languages compels us to redefine our conception of literature and provides a new context for understanding texts in European languages. We must rethink the articulation between local and global, and literary-verbal-practice is an excellent area for this kind of exercise. The weekly charts of literary magazines exist in what I call mondoromanzo, an analogy taken from the world of global winemaking: mondovino. In mondoromanzo the global bestseller overshadows all other kinds of verbal expression: fewer and fewer novels in French appear on these weekly charts, not to speak of novels in Dutch. Just as in mondovino, clever technician standardize wine production whatever the native soil, in mondoromanzo clever PR people produce 'above ground' literature, without any real roots.

Books are written in a language which is always a historical product. We non native English language speakers may write theory in English, but we write in our own languages when we write essays or poetry or fiction.

Post colonial criticism was going even further than Commonwealth criticism in its effacement of modern indigenous language expression in colonized countries... replacing ... a well meaning confusion with a definitive theoretical lock out (Barber 1995: 4).

Literary scholarship is on the wrong path if it emulates media and cultural studies which focus entirely on English medium productions: links cannot be cut to history, to time, to language and thus to

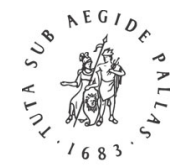

B R I L L 
philology. To achieve the alternative objectives needed for an African Renaissance, priorities must be set.

The first priority is the rewriting of literary history. The grand narrative of colonial imposition of European languages in Africa has to be contextualized, rewritten and long forgotten figures given due recognition. Literature provides us with many alternative memories that should be placed within the framework of this new history of literature. For instance, religious poetry such as the Nazarene hymns edited with a commentary by Gunner (2004) certainly belongs to this new history of literature! The second priority is the local literary scene and, of course, local languages. We need to edit, translate and comment on what is being done in these languages; we should remember that this material is difficult to grasp if we are not provided with historical information, which is too often lacking.

I will first give examples of what can be done, focusing on local literatures. At the same time I do not forget the world literary scene and the necessary African presence in that area. I conclude by proposing four pragmatic models of interaction between the local and the global scene offered to African authors.

\section{Rewriting the history of literature}

As we have remarked (Ricard and Veit-Wild 2005), African literature has long been used as a source of knowledge about life on the African continent, about colonial oppression, racism or gender. This legitimate interest is at the same time very reductionist. Writing from Africa should not merely be seen as a mirror of society. Scholars could question the status of literature within society and not only the image of the society within literary texts. Major writers have received far too little attention due to a lack of historical research and philological expertise. Karin Barber and Graham Furniss (2006: 14) insist on 'directing wide ranging questions to specific concrete texts or bodies of texts'. These questions fall into five categories: the interface with oral genres, the new written genres, such as the novel, the new ways of looking at the word, and, finally, new relations with the audience and an appropriation of literature for moral action (ibid.). This last theoretical stand is certainly not a novelty but in the mondoromanzo type of world novelistic economy it tends to be forgotten. A paradigmatic example of the Barber-Furniss approach is probably offered by

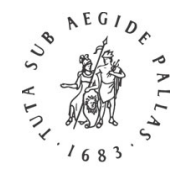

B R I L L 
the work of Thomas Mofolo, still widely read, but too often treated as if he were an Anglophone novelist. Africa is erased!

Thomas Mofolo (1877-1948) is best known as the author of Chaka (1926), a novel which today belongs to universal literature and has been translated into many languages. His first text, Moeti oa Bochabela (1907, French original translation: L'homme qui marchait vers le soleil levant, The Man Who Walked Towards the Rising Sun, 2003) makes him the first Sotho but probably also the first African novelist. This novel dominates Sotho literature and deserves more and special attention. A start is definitely provided by Kunene's excellent study (1989) which focuses on language. Moeti oa Bochabela is a prophetic and syncretic text, not a Calvinist demonstration, and certainly not an adaptation of the Pilgrim's Progress. Although it can possibly be read as a model of Sotho masculinity (Isabel Hofmeyer, The Portable Bunyan, 2004), the comparison with Bunyan's book, The Pilgrim's Progress (1954) does not help interpretation.

Fekisi, the hero, lives in the

old times, when this land of Africa was still clothed in great darkness, dreadful darkness, in which all the works of darkness were done. It is the days when there was no strong chieftainship, the tribes still ate each other (Mofolo 2003: 37, my translation from the French).

Fekisi searches for God and, rejecting the customs of his Sotho ancestors, finds the light of the Orient on Mount Sion (2003: 153). On the Son of Man's invitation to follow him, Fekisi enters the holy city where he reigns with God because he had no fear and left his country for the love of God. To create a new genre, as Thomas Mofolo did, is not simply to tell a long story on paper but also to tell a story which incorporates what has made possible the very act of its writing. The novelist is acutely conscious of the creation of a literary language. He tells something that has never before been told: leaving his culture, starting towards a new horizon, crossing the sea, encountering new peoples. The narrative starts from within the culture, not from an abstract world but one permeated with the sounds and the words of Sotho villages.

There is an important moment in chapter five, in the middle of the novel, when Fekisi decides to leave his village. Instead of simply turning his back on the pagans as we tend to believe he did from superficial accounts of the novel compounded by bad translations, Fekisi returns to his kraal. He talks to his cows, as Chaka would do

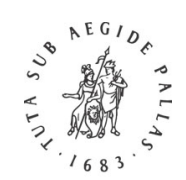

B R I L L 
some years later in another novel. As we know, cows play a central role in the religion of the Basotho. Moshesh could not circumcize his son if he did not spread the offals of a cow on the grave of his grandfather. Cows are not merely a meat reserve; they are memory and religious artefacts. The French translation by Ellenberger makes this abundantly clear: 'la vache, intermédiaire divin' in notes as well as in precise translations of Sotho terms. Where in English we have the 'girls', Ellenberger in French translates the Sotho term as the 'initiates', thus, telling quite a different story!

So what is our 'proto' Christian doing with these sacred cows? Are they not a hindrance to his progress as a Christian? What emerges from this chapter, a central chapter in the book, is not exactly the picture of a devout Christian rejecting his entire culture. Fekisi dreams, praises and then leaves. This is the individual quest of a man who is totally immersed in his own culture and who does not condemn the initiates, the bale. On the contrary, the animals are almost accomplices, encouraging him to go. This scene is extremely important. By performing the praise song, Fekisi places himself squarely within his culture and it is surely not a detail if he does so at the time of his departure. What is new in the novel is precisely this syncretism: verbal syncretism of praise eulogies spread throughout the narrative, as Kunene convincingly shows, and religious syncretism as we have tried to show. In a world heading towards separate development, this practical apologia of syncretism was doomed to fail and to remain misunderstood. In any case its subversive content was erased.

If the figure of the writer is partly the figure of a prophet, then Mofolo could be considered one of the Bantu prophets. As Paul Ricoeur (1983) would express it, the novelist reconfigures the world, gives a new figure to feelings and representations. He also creates a new language, still waiting to be used again. This is what the oral poet does with tradition. Moeti oa Bochabela reconfigures, in Paul Ricoeur's sense, the world experience of a Sotho shepherd in a totally new way. It is the story of a conversion, of a solitary adventure, in a society viewed by an individual who presents in a new way what has always been there.

Another example of an important and neglected figure is David Yali Manisi, an oral poet, an imbongi, reknown in the Thembu area, but unknown outside. Jeff Opland met him in 1970 and started a fruitful association with him up until the mid nineties. David Yali Manisi had celebrated the famous Thembu chiefs and their associates. In

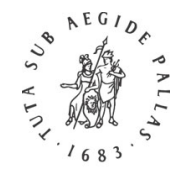

B R I L L 
the fifties he had composed poems to celebrate Kaiser Mathanzima, Sabatha Dalindyebo, and Nelson Mandela. Some of his poems were published in book form by Lovedale Press but remained unknown. Poetry in Xhosa was considered long dead: who was interested in such linguistic practices? Who mentioned them in the histories of literature in Southern Africa? Jeff Opland had studied medieval poetry; he was aware of the debate surrounding the oral nature of Homeric poetry and he realized that what Manisi was doing was exactly what Homeric scholars had studied in the Balkans a few decades earlier. He started to record and to translate Manisi's poems; he also edited them. In 1983 he published a groundbreaking book, Xhosa Oral Poetry, then in 1998 Xhosa Poets and Poetry, and finally in 2005, The Dassie and the Hunter, a personal account and analysis of his long association with the poet in the context of apartheid South Africa. A member of the African National Congress in the 1950s, David Yali Manisi was the official poet of the Transkei in the 1970s, one of the earliest Bantustans. His poems are impressive, even in translation: long, vibrant, full of images, direct. We can see clearly the filiation between his oral and literary style and rap poetry.

Unlike the poetry of Mqhayi, Manisi's poetry is neither well known nor widely appreciated. It needs to be understood as the product of one exponent of a well established tradition, a tradition in the process even now of redefining itself... (Opland 2005: 26).

This quote from Opland shows the extent of rewriting of history in which we need to connect contemporary 'bush' poets with well known literary figures: the tradition is not only the Xhosa tradition, it is the tradition of Oral poetry, and of its philological study. But to be able to know and appreciate these texts you need to undertake field research: philologists seldom do that these days! Few scholars with a background in general and comparative literature have studied African literature. What Opland has accomplished is truly remarkable because it maps for us a new province of African literature.

Examples of creativity and originality can be found in other linguistic areas. Mulokozi and Sengo's work on History of Kiswahili Poetry (1995) is a good example of the mapping of a new terrain. Mulokozi has studied the works of Habibu Selemani, a Muhaya poet and master of Enanga poetry in his book, The African Epic Controversy (2002). The impulse behind these seemingly diverse projects is the same: the need to rewrite the history of literature in Africa, the need to foreground

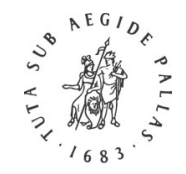

B R I L L 
original creative artists, too often neglected because of scholarly linguistic incompetence: again fieldwork is needed, not very rewarding at first and time consuming. Literary scholarship is also a branch of linguistic anthropology.

At the same time ideological factors were at work: the new intellectual elites who have mastered European languages claim a monopoly of discourse and a unique understanding of tradition. They project a rupture between oral and written literature which is absent in David Yali Manisi. This is not in line with older, native, indigenous modes of discourses, which for instance claim an African appropriation of Christianity or of Islam. Words and concepts from the native languages-morena: king in Sesotho for instance-are reinterpreted. The philological commentary is an hermeneutic exercise. The work of Elizabeth Gunner on Shembeian hymns is also truly groundbreaking in that sense in showing the combination of Zulu poems and Christian hymns. But the new forms bring new messages: Shembe's histories promote a rejection of the 'macho heroic ethic of warrior leadership' (Gunner 2004: 40) which has been the cornerstone of Zulu traditionalism from Chaka to Jacob Zuma! These hymns are a beautiful collection of African poetry in Zulu, but they were the sole patrimony of an African church until Elizabeth Gunner edited them with a commentary. Her work allows us new insight into Mofolo's prophetic wanderings in Southern Africa by inviting comparison with the narrative testimony of Meshack Hadebe (in Gunner 2004), one of the first writers from the Nazareth church.

The examples given above are typical of the rewriting being undertaken by some scholars of the history of literature in Africa. An African Renaissance, a true set of alternatives, requires these efforts. There will not be an original African literature if the work of African language pioneers and practitioners is not understood, studied, taught. This does not mean that there is a 'true' African literature only in African languages, just that important areas of African expression have been erased or neglected and that they should be brought to our attention.

\section{Local languages}

What Mofolo had to say needed a new language: in his case it was prose fiction, which he invented as an artistic medium in Sesotho.

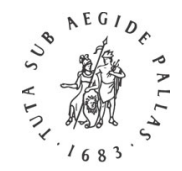

B R I L L 
The situation is the same in many languages if we assume from the start that the choice of language is the choice of a social and linguistic method in constructing an artistic world. This spiritual experience is thus a political gesture of a very practical kind, unfortunately tainted in many cases by the suspicion of an inferiority complex. Did these authors write in Shona or in Yoruba, because they could not write as successfully in English? Did others write in Kiswahili in the nineteenth century because Arabic was too difficult? This suspicion is very powerful and very harmful: it negates the positive component of language choice in favour of an instrumental strategy, of a so-called worldly wisdom that smacks of condescension. We can, with some imagination, understand the aspirations of these writers and respect their efforts. For several years I studied people who wrote in a minority language and felt that it was terribly wrong to reduce their choice to one by 'default'. These writers were often defenders of Christian (Kitereza 1980, Mnyampala 1965) or Muslim (Robert 1991) 'middle class' values, which had little appeal to cosmopolitan nationalist intellectuals or committed scholars. Some of these writers were mid level civil servants, or even catechists, had a family and children, did not have much money and seldom travelled: nothing fancy! They did not belong to our stereotype of the 'poète maudit', they were not a 'lost generation': they even tried to be models for their own people! Yet the political and ethical questions they posed-in the area of education for instance, on the meaning of tradition-were at the centre of efforts to produce a written version of their language in today's world. Should dialects be given a place? Should the standard language be chosen? What is the ethical value of traditional poetry if it promotes only values of violence and hierarchy? If, like in Rwandese 'Poèmes dynastiques', it is full of bloody killings? (Ricard 2005: 250).

At the same time, one never writes what one speaks: the creation of a written language is a dialogic process. What is written is an historical product handed down by committees, refined after countless hours of discussion, the product of a negotiated consensus. Can literature accommodate this spirit of consensus? When Serb and Croat diverge and there is no longer a Serbo-Croatian language, we see the linguistic harm done by the absence of a spirit of consensus. The writer is torn between a necessary language consensus and his own idiosyncratic view of the language and the world. Literature is first a practice, an 'artisanal' practice, and not a series of reified artefacts: it is a process, and not a product!

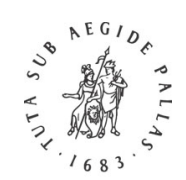

B R I L L 
Very few complete studies treat African writers as historical subjects trying to find a personal voice. The biographies of Dhlomo and Plaatje (1930), for instance, are all too rare examples. It is as if the stigma of elitism was attached to literature. Writers were too often felt to be aspiring petty bourgeois, if not real bourgeois; after all, Mofolo became a successful mine recruiter... Writers did not have the romantic appeal of the native perfomer for the anthropologist or of the peasant masses for the sociologist. I talked to many writers and was struck by their lucidity. In a way they are, by their very work, protesting against the uniformization of the world, against the domination of so-called world or imperial languages, be they English, French or Mandarin Chinese. The very act of writing one's own language in a creative way is an act of resistance against the posturing of globalization, the fallacy of monolingual multiculturalism. Africa has to be treated like the rest of the world and we have to translate and edit African texts to encourage young aspiring writers. Publishing at first abroad is not the only way to be read globally. Local relevance, philological expertise, verbal mastery have their own convincing 'global' dynamics! Our optimistic view is that a successful local writer will eventually achieve exposure to a broader world audience.

\section{Local literatures, global audiences?}

It has long been my conviction that the discussion and study of African language literatures is a major alternative to the reductionism of the so-called multiculturalist approach to literature. Multiculturalism without multilingualism is mere-well meaning?-posturing! But very few non native speakers are able to read works written in African languages. This narrow readership, narrow in the sense of shared cultural assumptions, is empoverishing African literatures. It took me, for instance, seven years to publish a translation prepared by former students of mine of Amegbetoa, a standard Ewe novel, unknown outside Ewe culture. Amegbetoa exists now in French. When I put it on the reading list of my African literature course, two years in a row, along with Chaka, I was extremely surprised by the positive reaction of young French students. They were fascinated by the story of a young man in search of justice, of the suffering of a just soul in pre-colonial Africa, in an Africa marked by its own social dynamic, and also its wars. Amegbetoa has a universal appeal, a sad austere

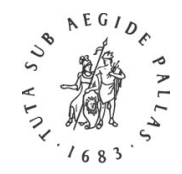

B R I L L 
quality that we find sometimes in Ewe singing. This beauty was felt by the students.

This was also the case with Chaka, an extraordinarily ambiguous book marked by a plurality of voice, where the Sotho tradition and heritage of negotiation is contrasted with the Zulu war tradition. In praise poetry and epic song one voice is heard. In Chaka the small voice of individual conscience is heard as well as the powerful voice of the group set against the examples of several possible ways to deal with the future. Why did such a powerful writer stop writing? In his excellent book, Thomas Mofolo and the Emergence of Written Sesotho Prose (1989), Dan Kunene provides a context of understanding through a careful philological reading but no definite answer. From my own study of Hussein (Ricard 2000) and risking a parallel, I would say that poor translations, resulting in simplified works with complexities and contradictions purposely (?) left out, may explain his silence.

My interest has long been for small regional languages, but whereas Dutch, Danish and Greek, for instance, have fewer speakers than many African languages, they are not considered inferior languages. African languages have been marked by a history of racism and denial of the capacity for intellectual achievement. For obvious reasons it is usually very difficult to make a comparative assessment of the literary situations in Zulu and in Yoruba, or in Kiswahili and in Hausa, or Amharic. Throughout the last three decades I have met with many African language writers. I have talked to them about their reasons for choosing to write in an African language, about their hopes, their frustrations. I also tried to publish works in translation with limited success. I adhere totally to what Edouard Glissant (1981: 318), the West Indian poet and thinker, said a quarter of century ago: that languages not written in the next century run the risk of slowly dying and that their situation is probably the symptom of a deeper spiritual and intellectual crisis.

In many African language literatures, creative writing is in a special predicament. It has a captive readership composed of school children and is often written by authors enjoying the sanctuary and prestige of language boards. This is economically satisfying for a few specialized publishers but is not the usual situation in which literature develops. Criticism is too often limited to language teachers and emphasizes educational problems. Few readers from outside the language community propose an interpretation; translations from other literatures are limited to excerpts from classical works. A modernist and

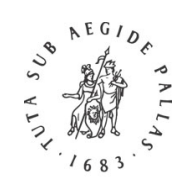

B R I L L 
innovative writer runs the risk of being neglected and not understood. But if recognition does not come from the linguistic community-the group of speakers and readers of the language-it will not come from without since so few works are translated. They may even be asked to translate themselves, a kind of spiritual harakiri for some of them, who refuse to obey the dictates of the captains of mondoromanzo! This is often the predicament of the writer in an African language. Most are bilingual but are not translated... Some African languages have a century old written literature, but in many cases these literatures are in intensive care. The example of Ebrahim Hussein, once the most famous playwright in Kiswahili, who has voluntarily stopped to write, is perhaps an indication of a predicament that may affect other writers. I believe that it is in the area of translation that a special effort has to be made to encourage writers and to let wider audiences share the experiences and the meanings offered by these works.

In Zimbabwe, writers like Charles Mungoshi and Chenjerai Hove chose to write and publish in both English and Shona. Their example in the seventies probably encouraged James Ngugi to break away from the format of the English modernist political novel and to create in his own language, Gikuyu, the first real novel (a long prose text and not a pamphlet). Pugliese (2006) discusses this question in a fascinating paper, providing historical depth to our reading of Ngugi. Ngugi articulated the theoretical basis of his break with English in several essays, especially Decolonising the Mind (1986): for him the only true 'African' literature is in an African language. His influence has been felt in a similar posture (break with the Europhone tradition) taken recently-and momentarily?-by Boris Boubacar Diop, for instance. We should, however, remain focused on those writers who have kept publishing in their own language and did not feel the need to publicize a long delayed, and sometimes short-lived, conversion. The novels of Mohammed Said Mohammed, Euphrase Kezilahabi, Said Ahmed Mohammed, W. Mkufya (see Garnier 2006) are already an important body of writing, which needs to circulate in translation and which shows what it means to write in one's own language.

It is thus very important to discuss Ngugi's break with English as a political posture and to place it against the backdrop of a continuous practice of writing in Kiswahili. The fact that these Tanzanian works have not been translated into English is just a testimony of the refusal to acknowledge cultural biodiversity: how can we expect to bridge the digital divide if we are not even capable of bridging a literary divide.

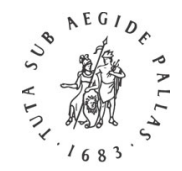

B R I L L 
Not a single modern Swahili novel (after Shaaban) has been translated into English! This is a kind of cold war waged against cultural diversity: no attention is paid to what is being said in Kiswahili; the only Tanzanian writers worthy of western media attention are long time expatriates in Toronto or London, who seem to capitalize on the appeal of Orientalism which is very successful in the West and in the North, and to benefit from the lack of translations of their Tanzanian colleagues. The same is true of an excellent-but mysterious-book like Abyssinian Chronicle, of which the original text (Abessijnse Kronieken (1998)) seems to have only a virtual reality: should we retranslate it from Dutch into English? Where is the manuscript: is it in English, in Dutch? Traceability is also required for this new brand of global cultural product!

\section{Towards a typology?}

From what I have written so far it is clear that I give high priority to local initiative, to what is expressed about Africa, from inside Africa, whatever the place or the language-African or European. Collecting more than eighteen hundred (1800!) pamphlets and novels in Hausa over the last decade, as Graham Furniss did, is testimony of the vitality of indigenous enterprise and publishing. Scholarship is too often written from outside, without contact with the sites of cultural production. The creation in the University of Kwazulu Natal of a Centre for African Literary Studies, the celebration in Dar es Salaam of the 75th anniversary of TUKI, the commitment by a South African Foundation to salvage and publish Timbuktu manuscripts are efforts going in the direction of reclaiming African scholarship for Africa. The continent's politics put a heavy burden on any practicing intellectual. He has to negotiate his position in his own society-the writer needs a language community; but he also has to have means of survival and, thus, an audience and the more global the better. I would like to propose a typology of attitudes chosen to deal with these constraints and to distinguish between embedded, diasporic, nomadic and commuting writers.

To be active in whatever language, on the local scene, is to be embedded: to have a local audience, in English, in French or in an African language. This is a new kind of commitment, perhaps the only commitment which is possible in today's Africa! of course, within the

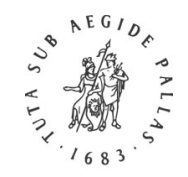

B R I L L 
local production African language books can be found. Femi Osofisan, the Nigerian poet and playwright, lecturer and journalist is a model of the embedded writer. Literature produced and read in Africa and quite obviously African language literature is our first, but not exclusive, concern. Too little is written on such literature for lack of information. However, distribution networks for African published books are starting to be developed (Afrilivres, African Book Collective) and bring to the North books published in the South. Journals can now be consulted on the net: Kwani in Kenya, edited by Binyawanga Vainana, Litnet in South Africa (http://www.litnet.co.za).

In former Zaire, in the 1970s and the 1980s, the great name of local literature was that of Zamenga Batukezanga, a novelist and philanthropist. He became the founder of an association to help the handicapped and was greatly respected for his social work. His books-narratives, novels-became well known inside his country but largely unknown outside. He was a perfect example of the writer practicing his craft to generate moral action, and he was doing it in French, verifying the remark that the language distinction is less salient in such works (Barber and Furniss 2006: 13) and that what is important is the local readership. Zamenga's generous outlook, his moral sense, his narrative abilities, made him the representative of a kind of commitment too often overlooked from abroad: a writer deeply embedded in his own society. Literature is truly for him equipment for living a better life, for reflecting upon values, for promoting solidarity and human respect. This kind of writer may seem very far from the dominant model in the North, but is a true alternative writer! Who could say that literature as a human enterprise is not well served by that bias?

Too often young writers are ignorant of the history of their people's literature: as we tried to show with Mofolo's example, much remains to be done to make it available to younger generations. It is easier to find any English Lit primer than to discover erudite editions of Swahili tenzi or Zulu praise poems. Fortunately some younger writers know their language history and have some sense of a literary heritage: for example, Nhanhla Maake, C.T. Msimang and M. Mulokozi. They belong to the category that I call embedded writers. Like many Tanzanians writers, working in Kiswahili, they live and work in their country and do not feel a need to write in another language.

The opposite attitude is that of writers who are considered by others to be African writers but who are perhaps more representative of a

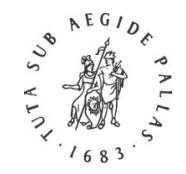

B R I L L 
so-called diasporic imaginary community: Tanzanian writers in exile, writing in English, Francophone Africans who have lived for a very long time in Europe, refugee writers who thematize their predicament but are somewhat detached from Africa and sometimes proud to be that way. The question of traceability then becomes important because diaspora is a real market, which tends to capture for their sole benefit the Northern and Western readership. Issues generated by the world success of Abessijnse Kronieken, come easily to mind. Diasporic books rarely make it to Africa. Their authors are successful expatriates and I do not think they can have much impact on their literary language community.

More interesting categories would be the nomadic and the commuting writers. The examples of the great commuter Wole Soyinka and of the emblematic nomad, Nuruddin Farah, come to mind. Wole Soyinka keeps his home base in Nigeria: he runs projects, has created a Foundation, commutes between Nigeria and the North where he can raise money and if need be, seek refuge. I believe he offers a convincing alternative of what an African writer's career can be. I think he has some influence on younger writers who understand that freedom can be gained at such a cost: many younger writers practice Soyinka's kind of dynamic and productive commuting, for instance Kangni Alem (2002).

Nuruddin Farah's attitude is different but presents the same commitment to Africa, even if his country is no longer on the map. Farah will not go into exile outside of Africa. He could become an expatriate, leaving the African continent, but refuses to do so. He has lived and taught in Nigeria, Uganda, and now South Africa. He is still a Somalian, but there is no Somalia. In one of his last books (2000) he travelled to meet with refugees from his country. He presents a nuanced picture of individual trajectories. In his novels he has analyzed the system of dictatorship. What is important is not the language he writes in, but the commitment he keeps to the welfare of Africa, to a solidarity with the continent, to a community of destiny. This is what makes Farah, like Soyinka, an African writer. If need be, or if possible-and it is not possible in Somalia-they remain embedded and do not aspire to perform solely on the diasporic scene. They are too well aware of the mondoromanzo type of posturing. Africanist scholars should also be aware of such confusion and take time to trace works, to contextualize and historicize them, as Opland, Gunner and Mulokozi do. The only

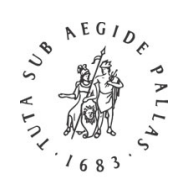

B R I L L 
alternative to the virtual Africa of mondoromanzo is the Africa that speaks, screams, writes: the Africa that produces ideas and verbal forms, the literature of Africa.

\section{References}

Alem, K. 2002. L'Atterrissage, suivi de: Dis moi, à quoi ça sert un écrivain en Afrique? de Emmanuel Dongala. Libreville, Ndzé.

Batukezanga, Z. 1982. Souvenirs du village. Kinshasa: Ed Saint-Paul Afrique.

Barber, K. 1995. African language literature and Post colonial Criticism, Research in African Literatures 26 (4) 3-30.

Barber, K. and G. Furniss (eds.) 2006. Special Issue, Creative Writing in African Languages, African language writing, Research in African Literatures 37 (3) 1-14.

Bunyan, J. 1954 (1678). The Pilgrim's Progress. London: Dent.

Couzens, T. 1985. The New African, A Study of the Life and Works of H.I.E. Dhlomo. Johannesburg: Ravan Press.

Farah, N. 2000. Yesterday, Tomorrow, Voice from the Somali Diaspora. London, New York: Cassel.

Garnier, X. 2006. Le roman swahili. Paris: Karthala.

Gérard, A. 1971. Four African Literatures: Xhosa, Sotho, Zulu, Amharic. Berkeley, Los Angeles CA: University of California Press.

1984. Thomas Mofolo ou les oublis de la mémoire française, Politique africaine 13, 8-20.

Glissant, E. 1981. Le Discours antillais. Paris: Le Seuil.

Gunner, E. (ed./translater) 2004. The Man of Heaven and the Beautiful Ones of God, Umuntu waseZulwini nabantu abahle bakaNkulunkulu. Scottsville: University of KwaZulu Natal Press.

Hofmeyr, I. 2004. The portable Bunyan. Johannesburg: Witwatersrand University Press.

Isegawa, M. 1998. Abessijnse Kronieken. Amsterdam: De Bezige Bij.

Kiteresa, A. 1980. Bwana Myombekere na Bibi Bugonoka na Ntulanalwa na Buliwahli. Dar es Salaam: Publishing House.

Kunene, D. 1989. Thomas Mofolo and the Emergence of Written Sesotho Prose. Johannesburg: Ravan Press.

Mnyampala, M. 1965. Diwani ya Mnyampala. Amsha, Dar es Salaam: Eastern Africa Publications.

Mofolo, T. 2003 (1907). Moeti oa Bochabela. Morija: Morija Sesuto Book Depot, 1907. (French original translation, L'homme qui marchait vers le soleil levant, translated by V. Ellenberger. Bordeaux: Confluences).

1910. Pitseng. Morija: Morija Sesuto Book Depot.

1981 (1926). Chaka. Morija: Morija Sesuto Book Depot, 1925 (English translation: Chaka, a New Translation, by D. Kunene, London: Heinemann).

Mulokozi, M. 2002. The African Epic Controversy: Historical, Philosophical and Aesthetic Perspectives on Epic Poetry and Performance. Dar es Salaam: Mkuki na Nyota.

Mulokozi, M. and T.S.Y. Sengo 1995. History of Kiswahili Poetry. Dar es Salaam: TUKI. Ngugi Wa Thiong'o 1986. Decolonising the mind. Oxford: James Currey.

Njogu, K. 2004. Reading Poetry as Dialogue. Nairobi: The Jomo Kenyatta Foundation.

Obianim, S. 1990 (1949). Amegbetoa, alo Agbezuge fe nutinya. London: Macmillan (French original translation, Amegbetoa ou les aventures d'Agbezuge. Paris: Karthala).

Opland, J. 1983. Xhosa Oral Poetry. Cambridge; New York: Cambridge University Press.

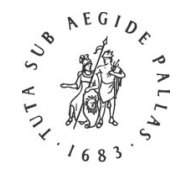

B R I L L 
1998. Xhosa Poets and Poetry. Cape Town: David Philip.

2005. The Dassie and the Hunter, A South African Meeting. Scottsville: University of Kwazulu Natal.

Plaatje, S.T. 1930. Mhudi. Alice: Lovedale Press.

Pugliese, C. 2006. Quel est le premier roman gikuyu? In X. Garnier and A. Ricard (eds.) L'effet roman: arrivée du roman dans les langues de l'Afrique. Paris, Université de Paris 13 CENEL: Harmattan, 145-152.

Ricard, A. 2000. Ebrahim Hussein, Swahili theater and Individualism. Dar es Salaam: Mkuki na Nyota.

2004. Languages and Literatures of Africa. Oxford, Trenton, Cape Town: James Currey, Africa World Press, David Philip.

2005. La formule Bardey. Bordeaux: Confluences.

Ricard, A. and F. Veit-Wild (eds.) 2005. The Oral Written Interface. Matatu: Rodopi.

Ricoeur, P. 1983. Temps et récit. Paris: Le Seuil.

Robert, S. 1991 (1966). Maisha yangu na baada Miaka Hamsini. Dar es Salaam: Mkuki na Nyota.

Soyinka, W. 2004. Climate of Fear. London: Profile Books.

Sundkler, B. 1949. Bantu Prophets. London: Lutterworth Press.

Willan, B. 1984. Sol Plaatje, A Biography. Johannesburg: Ravan Press.

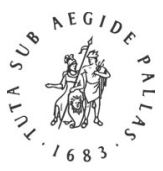

B R I L L 